WSRC-TR-95-0034

Revision 0

Keywords:

Vitrification, Hanford Site, Tank Waste Remediation systems (TWRS), Simplex algorithm

\title{
GLASS COMPOSITION DEVELOPMENT FOR VITRIFICATION OF HANFORD HIGH SODIUM CONTENT LOW-LEVEL RADIOACTIVE LIQUID WASTE
}

\author{
JAMES C. MARRA
}

SAVANNAH RIVER TECHNOLOGY CENTER

Publication Date: February 1995

Westinghouse Savannah River Company

Savannah River Site

Aiken, SC 29808

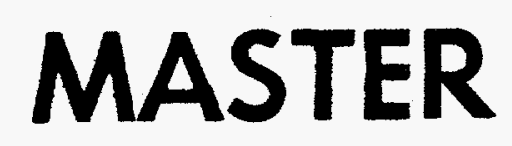

DISTRIBUTION OF THS DOCUMENT IS UNLIMITED 


\section{DISCLAIMER}

This report was prepared by Westinghouse Savannah River Company (WSRC) for the United States Department of Energy under Contract No. DE-AC09-89SR18035 and is an account of work performed under that contract. Neither the United States Department of Energy, nor WSRC, nor any of their employees makes any warranty, expresses or implied, or assumes any legal liability or responsibility for the accuracy, completeness, or usefulness, of any information, of any information, apparatus, or product or process disclosed herein or represents that its use will not infringe privately owned rights. Reference herein to any specific commercial product, process, or service by trademark, name, manufacturer or otherwise does not necessarily constitute or imply endorsement, recommendation, or favoring of same by WSRC or by the United States Government or any agency thereof. The views and opinions of the authors expressed herein do not necessarily state or reflect those of the United States Government or any agency thereof. 


\section{DISCLAIMER}

Portions of this document may be illegible in electronic image products. Images are produced from the best available original document. 
WSRC-TR-95-0034

Revision 0

Keywords:

Vitrification, Hanford Site, Tank Waste Remediation systems (TWRS), Simplex algorithm

Retention : Permanent

\section{GLASS COMPOSITION DEVELOPMENT FOR VITRIFICATION OF HANFORD HIGH SODIUM CONTENT LOW-LEVEL RADIOACTIVE LIQUID WASTE}

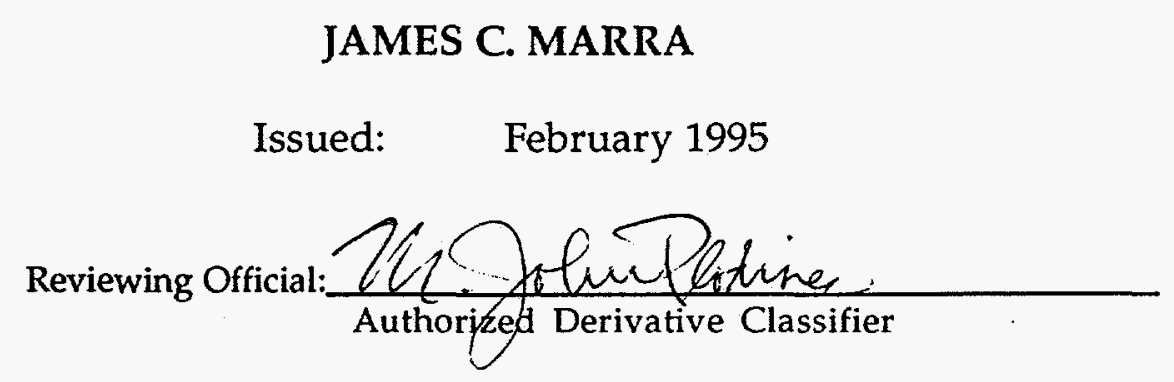

Patent Status:

This internal management report is being transmitted without DOE patent clearance, and no further dissemination or publication shall be made of the report without prior approval of the DOE-SR patent counsel.

Westinghouse Savannah River Company Savannah River Technology Center Aiken, SC 29808

PREP ARED FOR THE U.S. DEP ARTMENT OF ENERGY UNDER CONTRACT NO. DE-ACO9-89SR18035 


\section{WSRC-TR-95-0034}

Rev. 0

THIS PAGE INTENTIONALLY LEFT BLANK 
WSRC-TR-95-0034

Rev. 0

TABLE OF CONTENTS

Summary

Introduction

Properties and Optimization Criteria

Composition Batching and Melting

Results and Discussion

Joule Heated Melter Run

Low Boron Glass Compositions

Conclusions

References

\section{PAGE}

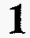

2

2

4

4

6

7

8

9 


\section{WSRC-TR-95-0034}

Rev. 0

THIS PAGE INTENTIONALLY LEFT BLANK 
WSRC-TR-95-0034

Rev. 0

\section{APPROVALS}

Gamea Plane James C. Marra, Author

Defense Waste Processing Technology Section

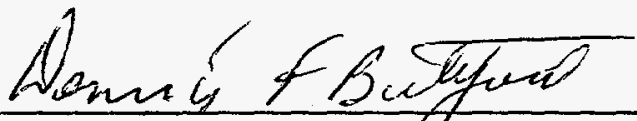

Dennis F. Bickford, Technical Reviewer

Defense Waste Processing Technology Section

71

M. John Plodinec, Senior Advisory Scientist

Defense Waste Processing Technology Section

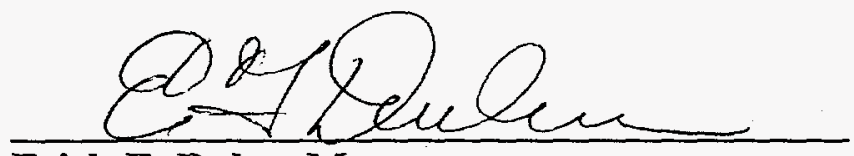

Erich F. Duhn, Manager

Defense Waste Processing Technology Section
Date: $2 / 2 / 95$

Date: $2 / 3 / 95$

Date: 32 tes 95 


\section{WSRC-TR-95-0034}

Rev. 0

THIS PAGE INTENTIONALLY LEFT BLANK 
WSRC-TR-95-0034

Revision 0

Keywords: Vitrification, Hanford Site, Tank Waste Remediation Systems (TWRS), simplex algorithm

Glass Composition Development for Plasma Processing of Hanford High Sodium Content Low-Level Radioactive Liquid Waste - (U)

\section{Summary}

A self-directed optimization approach was used to develop a glass composition for plasma vitrification of a high sodium content nuclear waste. To assess the acceptability of prospective compositions, response criteria based on durability, homogeneity, viscosity and volatility were defined. The response variables were weighted: durability $-35 \%$, homogeneity $-25 \%$, viscosity $-25 \%$, and volatility $-15 \%$. A Plackett-Burman experimental design was used to define the first twelve glass formulations [1]. Glass former additives included: $\mathrm{Al}_{2} \mathrm{O}_{3}, \mathrm{~B}_{2} \mathrm{O}_{3}, \mathrm{CaO}, \mathrm{Li}_{2} \mathrm{O}, \mathrm{ZrO}_{2}$ and $\mathrm{SiO}_{2}$. Lithia was added to facilitate fritting of the glass additives. The glass former additives were normalized to silica content to ease experimental matrix definition and glass formulation. Preset high and low values of these ratios were determined for the initial twelve melts. Based on the rankings of the initial compositions, new formulations for testing were developed based on a simplex algorithm. Rating and ranking of subsequent compositions continued until no apparent improvement in glass quality was achieved in newly developed formulations. An "optimized composition" was determined by averaging the additive component values of the final best performing compositions. The glass former concentrations to form the optimized glass were: 16.1 wt $\% \mathrm{Al}_{2} \mathrm{O}_{3}, 12.3$ wt $\% \mathrm{~B}_{2} \mathrm{O}_{3}, 5.5$ wt $\% \mathrm{CaO}, 1.7$ wt $\% \mathrm{Li}_{2} \mathrm{O}, 3.3$ wt $\% \mathrm{ZrO}_{2}$ and $61.1 \mathrm{wt} \% \mathrm{SiO}_{2}$. The power of this formulation development methodology was illustrated in that an optimized composition resulted after only 25 trials despite studying six glass additives.

A vitrification campaign was completed using a small-scale Joule heated melter. Approximately $80 \mathrm{lbs}$ of glass was produced over 96 hours of continuous operation. Several salt compounds formed and deposited on melter components during the run and likely caused the failure of several pour chamber heaters.

In an attempt to minimize sodium volatility, several low or no boron glasses were formulated. One composition, containing no boron, produced a homogeneous glass that is worthy of additional testing. 
James C. Marra

February 2, 1995
WSRC-TR-95-0034, Rev. 0

Page 2 of 34

\section{Introduction}

The Department of Energy (DOE) is mandated by an agreement with the Environmental Protection Agency and the state of Washington to expedite clean-up of the Hanford Site following many years of nuclear materials production. The agreement, commonly referred to as the "Tri-Party Agreement", calls for the vitrification of approximately 230,000 cubic meters of defense nuclear processing wastes currently stored in underground tanks at the Hanford Site [2]. The waste will be separated into a large volume low-level radioactive waste stream and a smaller volume high-level radioactive waste stream. The low-level waste stream will consist of primarily sodium nitrate and other nitrate salts concentrated in an alkaline, aqueous solution. The high sodium concentration presents several vitrification process challenges including difficulty in identifying an appropriate glass composition that will produce a durable waste form and issues regarding batch volatility.

A nominal surrogate waste composition, based on waste tank history and sampling, was defined for initial testing (Table I). Due to the high concentration of sodium and presence of other potential volatile species, a low melting temperature was desirable. Thus, formulation development was aimed at a glass which could be melted at $1150^{\circ} \mathrm{C}$.

\section{Properties and Optimization Criteria}

An optimal glass must be homogeneous, highly resistant to aqueous attack and have a satisfactory viscosity to facilitate processing. Surrogate waste glasses made from each specified composition were rated based on durability, viscosity, homogeneity and volatility. These four criteria were weighted on perceived importance as follows: durability $-35 \%$, viscosity $-25 \%$, homogeneity $-25 \%$, and volatility $-15 \%$.

Durability: The durability was assessed using the Product Consistency Test (PCT) [3]. The PCT evaluates the chemical durability of glasses by measuring the concentrations of the chemical species released from a crushed glass to a test solution. Although the elemental releases were normalized, releases for sodium were compared to the Environmental Assessment (EA) glass since sodium typically showed the greatest release and the sodium content remained constant for each glass (i.e. sodium only introduced from the waste). A zero was assigned to a tested composition if the measured elemental release was equivalent to or greater than the EA glass. A one was assigned to a glass if the elemental release was at least a factor of ten lower than the EA glass. A linear scale was used to assign a value for glasses between these two extremes. 
Viscosity: The viscosity was measured using a viscosity prediction model [4]. The model was developed using concepts of glass structure. This model predicts the viscosity of a given glass composition based on the effect of component cations on the glass structure. A non-bridging oxygen (NBO) parameter is calculated based on the cation species and concentrations. Elements such as alkalis (i.e. modifiers) increase the NBO term while elements such as alumina (i.e. network formers) decrease the NBO parameter. Utilizing the NBO term a viscosity is predicted as a function of temperature and composition. Extremely low viscosities can lead to excessive melt volatility and corrosion, while very high viscosities can hinder homogenization and glass pouring. Viscosity values less than 20 poise and greater than 200 poise were deemed unacceptable and values of 0 were assigned to these values. A 1 was assigned to a glass with a calculated viscosity between 60 and 140 poise. Following discussions with Westinghouse Science and Technology Center personnel, it was determined that glasses with viscosities up to 140 poise would readily pour from the plasma system. Viscosity values lying between this range and the extreme values were scaled linearly to give a viscosity response value between 0 and 1 .

Homogeneity: The homogeneity of the glasses was evaluated by visual examination. A 0 was assigned if only crystalline phases were formed. A 1 was given to a formulation which visually appeared entirely glassy. A value of 0.5 was given to a composition which had both glass and crystalline phases present.

Volaitity: In this approach, volatility is quantified by measuring the amount of gall formation on the melt surface. Following melting of each composition, any gall or salt layer is separated and weighed. A value of 0 to 1 is obtained by the equation: Volatility $=1-\mathrm{Wt}$ (gall)/Wt(worst case gall). A value of 0 is assigned to the melt containing the most gall, while a value of 1 is given to a sample with no gall layer. It is noted that no gall layer was seen during testing so the methodology was not employed and each composition received the maximum rating.

Optimization Criteria: For each composition the above determined values were multiplied by the weighting for each criteria. These values were added together to give a total "desirability quantity" for the respective composition. A maximum value of 100 could thus be achieved.

A simplex algorithm was used to develop additional glass formulations and eventually focus in on the optimal composition [5]. The first twelve glasses (using the PlackettBurman matrix) were ranked according to the desirability quantity. The four "worst" glasses were used to generate four new glasses and were replaced. The composition of each poor glass was subtracted from twice the average of the eight better glasses. The four new glasses were formulated, melted, characterized and ranked with the eight 
better glasses. The new ranking then provided four poor glasses which were replaced in round 3 by the same methodology. The methodology was continued for 4 rounds (24 glasses) until it was apparent that little improvement on the eight better glasses would result from the subsequent 4 new formulations. An optimized composition was determined by averaging the eight best glasses following round 4 .

\section{Composition Batching and Melting}

The glass additive compositions for each of the 25 glasses are shown in Table II. The first twelve compositions were determined by a Plackett-Burman design. All glasses were formulated using reagent grade chemicals. Alumina, silica and zirconia were added as their oxides. Calcia and lithia were introduced as carbonates while boria was added as boric acid. A waste loading of $25 \%$ on a calcined oxide basis was used in the formulations. The "waste" was added as a $10 \mathrm{M} \mathrm{Na}+$ solution (obtained from Optima Chemical, Douglas, GA) with the composition given in Table I. The solution was a surrogate for the Hanford Double Shell Slurry Feed (DSSF) waste. Glasses were melted at $1150^{\circ} \mathrm{C}$ for 2 hours in covered alumina crucibles and allowed to air cool in the crucibles.

\section{Results and Discussion}

The rankings and respective numerical values for the response variables for the first twelve glasses are shown in Table III. The four "poor" glasses are separated from the eight "best". Ten of the twelve compositions produced at least some glass (Figures 1 and 2). Compositions 5 and 11 resembled a crystallized glass-ceramic. The nominal glass composition, which formed the basis of the Plackett-Burman matrix, is also shown. This nominal composition was also batched and melted without lithia addition in an attempt to minimize alkali content in the glass. Both of these formulations were somewhat cloudy with significant undissolved batch present.

Four new glasses (compositions 13-16) were formulated and melted based on the round 1 results (Figure 2). A ranking of the glasses following second round testing is shown in Table IV. Composition 14 was not an improvement on the glasses from round 1. This illustrates an important point regarding this optimization methodology. There is no guarantee that a new composition will be an improvement on the previous compositions. It may overshoot the optimal region altogether as was the case with composition 14. However, as long as there is some progress with the new formulations, the optimal region will be approached. It must be noted that an error was made in the initial calculation of the durability rating for composition 16 in this round. The error allowed composition 16 to mistakenly replace composition 13 in the 
eight best rankings. A computational exercise revealed that this error made little difference to the final averaged composition. The largest variation occurred in boria which differed by approximately $0.5 \mathrm{wt} \%$ as measured in the final glass.

Compositions 17-20 were melted in round 3 based on the results of round 2 (Figures 2 and 3). In this round Composition 19 did not improve on the glass it replaced (Table V). Although composition 20 did better than the glass it replaced, it did not rank in the eight best compositions.

In round 4, compositions 21-24 were prepared (Figure 4). Only formulation 21 ranked in the eight best compositions following this round (Table VI). At this point it was decided that continued formulation development would not significantly improve or change the best eight glasses. In an attempt to identify a centralized glass formulation in the compositional space for these best eight glasses, the glass former concentrations were averaged to produce a "best average composition". A uniform glass resulted from the best average formulation (Figure 5). The glass composition is listed in Table VII. The influence of glass former concentration levels and interactions on glass quality became apparent during the optimization exercise. Typically a low level of lithia with an elevated level of boria constituted a good glass. In the initial Plackett-Burman compositions, a high level of alumina or zirconia but not both produced the better glasses. It later became apparent that moderate levels of alumina produced good glasses as long as the boria levels were not excessive and the lithia levels were very low. Low zirconia levels were prevalent in the eventual best eight glass compositions. Calcia levels appeared to have no relationship to the quality of glasses produced. However, it must be noted that the calcia concentration was flexed the least in defining the initial high and low glass former levels.

During the formulation rating process some important observations were made. The importance of properly selecting the response variable values and scaling must not be overlooked. Careful consideration was made at the onset of this program to select appropriate acceptable response variable values. Although these selections seemed adequate, two areas for possible improvement are cited. Table VIII lists the PCT normalized elemental release values for the best eight glasses. The glasses are ranked in descending order based on the elemental releases compared to the EA glass. All the glasses had elemental releases close to or better than 10 times lower than the EA glass and thus were assigned high ratings. However, the most durable glasses had releases nearly 3 times lower than the less durable glasses. Similarly, the relatively broad range of acceptable viscosity values may have "over-rewarded" certain formulations. An optimal viscosity of 100 poise at $1150^{\circ} \mathrm{C}$ was initially prescribed. In the best eight compositions, several received a 1 viscosity rating based on the selected criteria but 
James C. Marra

February 2, 1995
WSRC-TR-95-0034, Rev. 0

Page 6 of 34

were located near the extremes of the acceptable region (Table IX). It is not apparent if a change in these rating parameters would have affected the optimization experimentation significantly, but it is obvious that selecting appropriate response values is paramount to the success of this optimization methodology.

The sensitivity of the ratings must also be carefully considered individually and collectively. This is especially apparent when somewhat judgmental criteria are used in the rating scheme. In several instances glasses had the same or very similar ratings. This made distinguishing the quality of the glasses difficult. This was especially perplexing when the closely ranked glasses were at the cut-off line between the best eight and the four poor glasses (e.g. following round 2). In cases of identical rankings the most durable glass was ranked higher. However, when glasses had very similar ratings the higher scoring composition was promoted. The possibility of advancing a poorer composition became apparent in these instances. Developing more discrete rating criteria would undoubtedly alleviate this problem.

\section{Joule Heated Melter Run}

In order to examine the feasibility of processing the waste glass compositions in a continuous melter, a small-scale vitrification campaign was performed. The Joule heated melter in building 774-A was used in this test. A continuous run of at least three melter turnovers ( 1 melter turnover $\approx 22 \mathrm{lbs}$ ) was desired. The actual run exceeded this requirement as the melter operated for approximately 96 hours producing approximately $80 \mathrm{lbs}$ of simulated waste glass.

Waste glass composition 4 was selected for this application. A small amount of $\mathrm{Fe}_{2} \mathrm{O}_{3}$ was added to the glass additives to satisfy a request by the Hanford customer. Composition 4 was modified by adding $1.5 \mathrm{wt} \% \mathrm{Fe}_{2} \mathrm{O}_{3}$ to the glass additive concentration (1.1 wt \% in the final glass) at the expense of alumina. Simulated Hanford DSSF waste was added to the glass additives in a mixing tank to achieve a waste loading of $25 \mathrm{wt} \%$ on a dry oxide basis. Distilled water was added to the mixing tank to obtain the desired $40 \%$ solids content necessary for successful operation of the existing slurry feed system. The glass additive concentration and theoretical final glass composition are listed in Table X.

A cold top melter condition was desirable for this run. It was difficult to ascertain if this was achieved due to clouding of the melter sight ports. The corrosive nature of the melt (as described below) indicated that a sufficient cold cap was not maintained. A melt temperature of $1150^{\circ} \mathrm{C}$ was maintained for the duration of the campaign. 
Attempts were made to maintain the melter pour chamber at $850^{\circ} \mathrm{C}$. Several failures of the pour chamber heaters made this difficult.

During the melter campaign several deposits (containing chlorine, sulfur and phosphorous) formed during the run and deposited on various melter and off-gas system components. The salts likely caused the failure of several dome heaters in the pour chamber. Deposits were examined by scanning electron microscopy (SEM) coupled with energy dispersive spectroscopy (EDS). Chlorine was prevalent on the failed lid heater wire (Figure 6) likely causing the failure. Chlorine, sulfur and phosphorous were found in a failed lid heater thermocouple deposit (Figure 7). Chloride rich deposits were found in the inside neck of the melt chamber (Figure 8) and at off-gas system connection to the melter (Figure 9). The most unique deposits were found on the external, top of the melter and in the pour chamber view port (Figure 10). The spherical particles contained both chlorine and sulfur and ranged in size from less than $1 \mu \mathrm{m}$ to greater than $20 \mu \mathrm{m}$.

The resulting glass product was a blackish, brown due to the additional iron in the glass (Figure 11). Optical microscopy, SEM/EDS, and x-ray diffraction (XRD) revealed that a generally homogeneous glass product was produced. A very minor crystalline phase was observed in one of the glass samples. This phase was identified as sodium aluminum silicate sulfate by XRD. Glasses from cans 4,8 , and 9 were subjected to a 7-day Product Consistency Test (PCT) to assess glass durability. The results for glass samples from cans 8 and 9 are shown in Table XI. The normalized elemental releases were well below the EA glass releases. It was observed in the WSTC plasma vitrification trials that roughly $15 \%$ of the sodium and $20 \%$ of the boron volatilized in the melting process. Assuming similar volatilization levels occurred in this campaign, the results are comparable to the composition 4 crucible melt (Table VIII). The releases from can 4 were significantly higher. This was anticipated since the resulting glass was a combination of the feed material and the glass in the melter from a previous campaign.

\section{Low Boron Glass Compositions}

Glass composition 4 was used for the vitrification trials at the Westinghouse Waltz Mill Plasma Center by the Westinghouse Science and Technology Center. Significant sodium and boron volatility was apparent following analysis of the plasma melter cupola and off-gas components. Approximately $15 \%$ of the sodium and $20 \%$ of the boron were not incorporated in the glass. A significant amount of the loss was attributed to the formation of volatile sodium borate compounds. It was hypothesized 
that the use of low boron glass compositions would minimize the formation of these species and reduce sodium volatility. Following discussions with Joe Hammel, consultant to WSTC, ten potential low or no boron glasses were formulated. Five of these glasses were batched and melted (Table XII and Figure 12). Two of the glasses were melted at $1150^{\circ} \mathrm{C}$ while three were melted at $1275^{\circ} \mathrm{C}$. Two of the glasses JM-3 and JM-5 formed homogeneous glass. Composition JM-3 was also successfully melted at $1175 \mathrm{C}$, however, a high concentration of bubbles resulted in the glass implying a relatively high viscosity. Composition JM-3 contained no boron and is well situated in the glass forming region of the soda-lime-silica/alumina glass system [6]. This glass is being subjected to a 7-day PCT to assess the durability. Assuming adequate durability, this composition is a good candidate for additional testing.

\section{Conclusions}

An optimized glass composition to vitrify a high sodium content low-level radioactive waste was developed using a self-directed optimization approach. Response variable criteria for durability, viscosity, homogeneity and volatility were developed to compare prospective waste glass compositions. The power of this methodology was evident by the fact that only 25 glass melts were required to approach an optimized composition. The importance of properly selecting the response variable criteria was evident during the rating of the glasses and is considered a vital element for successful use of this optimization approach.

A campaign was successfully completed in a small-scale Joule heated melter. Approximately $80 \mathrm{lbs}$ of surrogate waste glass was produced over a 96 hour period of continuous operation. Several salt compounds deposited on melter and off-gas components during the melter run.

Several low and no boron content glasses were formulated in an attempt to minimize sodium volatility. One composition, containing no boron, is a good candidate for additional testing. 
James C. Marra

February 2, 1995
WSRC-TR-95-0034, Rev. 0

Page 9 of 34

\section{References}

1. "Strategy of Experimentation", E. I. duPont de Nemours \& Co., Wilmington, DE, 1988.

2. "Request for Proposal No. W-04579-LR for Glass Melter System Technologies for Vitrification of High-Sodium Content Low-Level Radioactive Liquid Wastes", 9451379, PMM-DVW-164, February 25, 1994.

3. C. M. Jantzen, N. E. Bibler, D. C. Beam, W. G. Ramsey and B. J. Waters, "Nuclear Waste Glass Product Consistency Test (PCT) - Version 5.0 (U)", WSRC-TR-90-539, Rev. 2, January, 1992.

4. A. L. Kielpinski, "Evaluation of DWPF Viscosity Processing Algorithm for Mixed Wastes: I. Alkali and Alkaline Earth Effects (U), WSRC-TR-94-0264, 1994.

5. P. D. Soper, D. D. Walker, M. J. Plodinec, G. J. Roberts and L. F. Lightner, "Optimization of Glass Composition for the Vitrification of Nuclear Waste at the Savannah River Plant", Ceramic Bulletin, Vol. 62, No. 9, p. 1013, 1983.

6. C. M. Jantzen, Personal Communication, January 13, 1995. 
James C. Marra

February 2, 1995
WSRC-TR-95-0034, Rev. 0

Page 10 of 34

Table I. $10 \mathrm{M} \mathrm{Na}^{+}$Simulant Composition

Oxide

$\mathrm{Al}_{2} \mathrm{O}_{3}$
$\mathrm{CaO}$
$\mathrm{Cr}_{2} \mathrm{O}_{3}$
$\mathrm{Fe}_{2} \mathrm{O}_{3}$
$\mathrm{~K}_{2} \mathrm{O}$
$\mathrm{MgO}$
$\mathrm{MnO}_{2}$
$\mathrm{MoO}_{3}$
$\mathrm{Na}_{2} \mathrm{O}$
$\mathrm{SrO}$
$\mathrm{Cs}_{2} \mathrm{O}$
$\mathrm{P}_{2} \mathrm{O}_{5}$
$\mathrm{NaI}$
$\mathrm{NaCl}$
$\mathrm{NaF}$
$\mathrm{SO}_{3}$

TOTAL
Calcined Solid (wt \%)

12.76

0.01

0.16

0.01

5.78

0.01

0.01

0.60

72.56

0.43

0.59

0.75

0.62

2.29

2.58

0.84

100 
James C. Marra

February 2, 1995
WSRC-TR-95-0034, Rev. 0

Page 11 of 34

Table II. Glass Additive Compositions for 25 Tested Glasses

Composition $\quad \mathrm{Al}_{2} \mathrm{O}_{3} / \mathrm{SiO}_{2} \quad \mathrm{~B}_{2} \mathrm{O}_{3} / \mathrm{SiO}_{2} \quad \mathrm{CaO} / \mathrm{SiO}_{2} \quad \mathrm{Li}_{2} \mathrm{O} / \mathrm{SiO}_{2} \quad \mathrm{ZrO}_{2} / \mathrm{SiO}_{2}$

$\begin{array}{llllll}1 & 0.23 & 0.22 & 0.07 & 0.08 & 0.16 \\ 2 & 0.23 & 0.22 & 0.11 & 0.08 & 0.05 \\ 3 & 0.23 & 0.09 & 0.11 & 0.02 & 0.16 \\ 4 & 0.35 & 0.22 & 0.11 & 0.02 & 0.05 \\ 5 & 0.35 & 0.09 & 0.11 & 0.08 & 0.16 \\ 6 & 0.35 & 0.22 & 0.07 & 0.02 & 0.05 \\ 7 & 0.35 & 0.22 & 0.07 & 0.08 & 0.16 \\ 8 & 0.23 & 0.22 & 0.11 & 0.02 & 0.16 \\ 9 & 0.23 & 0.09 & 0.07 & 0.08 & 0.05 \\ 10 & 0.23 & 0.09 & 0.07 & 0.02 & 0.05 \\ 11 & 0.35 & 0.09 & 0.07 & 0.02 & 0.16 \\ 12 & 0.35 & 0.09 & 0.11 & 0.08 & 0.05 \\ 13 & & & & & \\ 14 & 0.20 & 0.09 & 0.11 & 0.005 & 0.02 \\ 15 & 0.32 & 0.09 & 0.07 & 0.005 & 0.13 \\ 16 & 0.20 & 0.22 & 0.07 & 0.005 & 0.02 \\ & 0.20 & 0.22 & 0.07 & 0.06 & 0.02 \\ 17 & & & & & \\ 18 & 0.15 & 0.25 & 0.07 & 0 & 0.08 \\ 19 & 0.27 & 0.25 & 0.11 & 0.04 & 0.08 \\ 20 & 0.27 & 0.12 & 0.11 & 0 & 0 \\ & 0.18 & 0.25 & 0.11 & 0.06 & 0 \\ 21 & & & & & \\ 22 & 0.27 & 0.30 & 0.07 & 0.03 & 0 \\ 23 & 0.30 & 0.17 & 0.11 & 0 & 0.11 \\ 24 & 0.23 & 0.27 & 0.07 & 0.05 & 0.13 \\ & 0.32 & 0.14 & 0.07 & 0 & 0.13 \\ \text { Best Average } & 0.26 & 0.20 & 0.09 & 0.03 & 0.05\end{array}$


James C. Marra

February 2, 1995
WSRC-TR-95-0034, Rev. 0

Page 12 of 34

Table III. Ratings and Ranking after Round 1

Composition

Durabilit

35
35
35
31.2
35
35
35
35

35

27.3

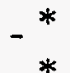

25

25

24.5

25

25

25

12

6.5

13.5

4.5

25

2.4
Homogeneity

25

25

25

25

12.5

12.5

25

25

12.5

25

0

0
Volatility Total

15

15

15

15

15

15

15

15

15

15

15

15
100

100

99.5

96.2

87.5

87.5

87

81.5

76

71.8

11

* PCT not performed - did not form glass

Table IV. Ratings and Ranking after Round 2

Composition

4

6

15

8

9

13

3

16

12

10

1

14

\section{Durabilit}

35

35

35

35

31.2

35

35

30.8

35

35

35

- *
Viscosity

25

25

25

24.5

25

16.8

25

15.5

25

12

6.5

0
Homogeneity

Volatility

15

15

15

15

15

15

15

15

25

12.5

15

15

15

25

0
Total

100

100

100

99.5

96.2

91.8

87.5

$86.3^{\circ}$

87.5

87

81.5

* PCT not performed - did not form glass

- Note: a calculation error in the durability rating caused this composition to inadvertently displace composition 12 . 
James C. Marra

February 2, 1995
WSRC-TR-95-0034, Rev. 0 Page 13 of 34

Table V. Ratings and Ranking after Round 3

Composition

Durability

Viscosity

Homogeneity

Volatility

Total

4

15

8

9

13

18

17

3

16

20

19
35

35

35

35

31.2

35

35

35

35

30.8

$-{ }^{*}$
25

25

25

24.5

25

16.8

16.2

25

25

15.5

6.5

6.5
25

25

25

25

25

25

25

12.5

12.5

25

25

12.5
15

15

15

15

15

15

15

15

15

15

15

15

* PCT not performed - did not form glass

Table VI. Ratings and Ranking after Round 4

Composition Durability Viscosity Homogeneity Volatility Total

$\begin{array}{rlllll}4 & 35 & 25 & 25 & 15 & 100 \\ 6 & 35 & 25 & 25 & 15 & 100 \\ 15 & 35 & 25 & 25 & 15 & 100 \\ 8 & 35 & 24.5 & 25 & 15 & 99.5 \\ 21 & 33.8 & 25 & 25 & 15 & 98.8 \\ 9 & 31.2 & 25 & 25 & 15 & 96.2 \\ 13 & 35 & 16.8 & 25 & 15 & 91.8 \\ 18 & 35 & 16.2 & 25 & 15 & 91.2 \\ 17 & & & & & \\ 23 & 35 & 25 & 12.5 & 15 & 87.5 \\ 22 & 33.9 & 12.5 & 25 & 15 & 86.4 \\ 24 & -* & 25 & 12.5 & 15 & - \\ & -* & 0 & 0 & 15 & -\end{array}$

* PCT not performed - did not form glass 
James C. Marra

February 2, 1995
WSRC-TR-95-0034, Rev. 0

Page 14 of 34

Table VII. "Best Average" Glass Composition

$\begin{array}{lcc}\text { Oxide } & \text { Glass Additive (wt \%) } & \text { Final Glass (wt \%) } \\ \mathrm{SiO}_{2} & 61.1 & 46.08 \\ \mathrm{Al}_{2} \mathrm{O}_{3} & 16.1 & 15.35 \\ \mathrm{~B}_{2} \mathrm{O}_{3} & 12.3 & 9.28 \\ \mathrm{CaO} & 5.5 & 4.15 \\ \mathrm{ZrO}_{2} & 3.3 & 2.49 \\ \mathrm{Li}_{2} \mathrm{O} & 1.7 & 1.28 \\ \mathrm{Na}_{2} \mathrm{O} & & 19.06 \\ \mathrm{~K}_{2} \mathrm{O} & & 1.45 \\ \mathrm{SO}_{3} & & 0.21 \\ \mathrm{P}_{2} \mathrm{O}_{5} & & 0.19 \\ \mathrm{MoO}_{3} & & 0.15 \\ \mathrm{Cs}_{2} \mathrm{O} & & 0.15 \\ \mathrm{SrO} & & 0.11 \\ \mathrm{Cr}_{2} \mathrm{O}_{3} & & 0.04 \\ \mathrm{Fe}_{2} \mathrm{O}_{3} & & 0.004 \\ \mathrm{MgO}^{\mathrm{MnO}} & & 0.002 \\ & & 0.002 \\ \mathrm{TOTAL} & & \\ & & 99.998\end{array}$


James C. Marra

February 2, 1995
WSRC-TR-95-0034, Rev. 0

Page 15 of 34

Table VIII. Normalized PCT Results for Final "Best Eight" and "Best Average" Glasses

\begin{tabular}{|c|c|c|c|c|c|}
\hline \multirow[b]{2}{*}{ Composition } & \multirow[b]{2}{*}{$\begin{array}{c}\text { Durability } \\
\text { Rating }\end{array}$} & \multicolumn{4}{|c|}{ Normalized Release $(\mathrm{g} / \mathrm{L})$} \\
\hline & & $\mathrm{Na}$ & Si & B & $\mathbf{L i}$ \\
\hline 8 & 35 & 0.568 & 0.123 & 0.449 & 0.231 \\
\hline 6 & 35 & 0.502 & 0.134 & 0.549 & 0.270 \\
\hline 4 & 35 & 0.609 & 0.112 & 0.630 & 0.284 \\
\hline 13 & 35 & 0.610 & 0.079 & 0.726 & 0.185 \\
\hline 15 & 35 & 0.685 & 0.099 & 0.940 & 0.364 \\
\hline Best Average & 35 & 0.732 & 0.119 & 0.792 & 0.430 \\
\hline 18 & 35 & 1.055 & 0.160 & 1.116 & 0.756 \\
\hline 21 & 33.8 & 1.382 & 0.209 & 1.771 & 1.516 \\
\hline 9 & 31.2 & 1.463 & 0.344 & 0.808 & 0.895 \\
\hline Glass & & 46 & 3.922 & 16.695 & 65 \\
\hline
\end{tabular}

Table IX. Predicted Viscosities for Final "Best Eight" and "Best Average" Glasses

$\begin{array}{cccc}\text { Composition } & \begin{array}{c}\text { Viscosity } \\ \text { Rating }\end{array} & \begin{array}{c}\text { Predicted } \\ \text { Viscosity (Poise) }\end{array} & \begin{array}{c}\text { Deviation } \\ \text { from 100 poise }\end{array} \\ 4 & & 94.8 & -5.2 \\ \text { Best Average } & 25 & 84.1 & -15.9 \\ 15 & 25 & 116.0 & +16.0 \\ 6 & 25 & 125.5 & +25.5 \\ 9 & 25 & 65.9 & -34.1 \\ 21 & 25 & 65.4 & -34.6 \\ 8 & 25 & 59.2 & -40.8 \\ 18 & 24.5 & 45.9 & -54.1 \\ 13 & 16.2 & 159.8 & +59.8\end{array}$


James C. Marra

February 2, 1995
WSRC-TR-95-0034, Rev. 0

Page 16 of 34

Table X. Glass Additive and Final Glass Concentration for Joule Heated Melter Run

$\begin{array}{lcc}\text { Oxide } & \text { Glass Additive (wt \%) } & \text { Final Glass (wt \%) } \\ & & \\ \mathrm{SiO}_{2} & 57.20 & 43.14 \\ \mathrm{Al}_{2} \mathrm{O}_{3} & 18.60 & 17.24 \\ \mathrm{~B}_{2} \mathrm{O}_{3} & 12.60 & 9.50 \\ \mathrm{CaO} & 6.20 & 4.68 \\ \mathrm{ZrO}_{2} & 2.80 & 2.11 \\ \mathrm{Fe}_{2} \mathrm{O}_{3} & 1.50 & 1.14 \\ \mathrm{Li}_{2} \mathrm{O} & 1.10 & 0.83 \\ \mathrm{Na}_{2} \mathrm{O} & & 19.06 \\ \mathrm{~K}_{2} \mathrm{O} & & 1.45 \\ \mathrm{SO}_{3} & & 0.21 \\ \mathrm{P}_{2} \mathrm{O}_{5} & & 0.19 \\ \mathrm{MoO}_{3} & & 0.15 \\ \mathrm{Cs}_{2} \mathrm{O} & & 0.15 \\ \mathrm{SrO} & & 0.11 \\ \mathrm{Cr}_{2} \mathrm{O}_{3} & & 0.04 \\ \mathrm{MgO}^{\mathrm{MnO}} & & 0.002 \\ & & 0.002 \\ \mathrm{TOTAL} & & \\ & & 100.004\end{array}$

Table VIII. Normalized PCT Results for 774-A Melter Run

Normalized Release (g/L)

Composition

Can 8
Can 9

EA Glass
$\mathrm{Na}$

0.302

0.287

13.346

Si

B

$\mathbf{L i}$

0.193

0.469

0.438

0.363

0.204

16.695

3.922

0.540

9.565 
James C. Marra

February 2, 1995
WSRC-TR-95-0034, Rev. 0

Page 17 of 34

Table XII. Glass Additive and Final Glass Concentrations for Low/No Boron Glasses

\section{Glass Composition (wt \%)}

Oxide Comp. JH-1 Comp. JH-3 Comp. JM-2 Comp. JM-3 Comp JM-5

$\begin{array}{lccccc}\mathrm{SiO}_{2} & 43.12 & 43.12 & 53.17 & 53.93 & 52.42 \\ \mathrm{Na}_{2} \mathrm{O} & 19.05 & 19.05 & 19.06 & 19.06 & 19.06 \\ \mathrm{Al}_{2} \mathrm{O}_{3} & 17.91 & 17.91 & 12.26 & 12.26 & 12.26 \\ \mathrm{~B}_{2} \mathrm{O}_{3} & 0 & 0 & 2.26 & 0 & 2.26 \\ \mathrm{CaO} & 13.35 & 11.69 & 6.04 & 7.55 & 7.17 \\ \mathrm{ZrO}_{2} & 2.11 & 2.11 & 3.02 & 3.02 & 3.77 \\ \mathrm{Fe}_{2} \mathrm{O}_{3} & 0.50 & 0.50 & 0.004 & 0.004 & 0.76 \\ \mathrm{Li}_{2} \mathrm{O} & 1.66 & 3.32 & 1.88 & 1.88 & 0 \\ \mathrm{~K}_{2} \mathrm{O} & 1.45 & 1.45 & 1.45 & 1.45 & 1.45 \\ \mathrm{SO}_{3} & 0.21 & 0.21 & 0.21 & 0.21 & 0.21 \\ \mathrm{P}_{2} \mathrm{O}_{5} & 0.19 & 0.19 & 0.19 & 0.19 & 0.19 \\ \mathrm{MoO}_{3} & 0.15 & 0.15 & 0.15 & 0.15 & 0.15 \\ \mathrm{Cs}_{2} \mathrm{O} & 0.15 & 0.15 & 0.15 & 0.15 & 0.15 \\ \mathrm{SrO} & 0.11 & 0.11 & 0.11 & 0.11 & 0.11 \\ \mathrm{Cr}_{2} \mathrm{O}_{3} & 0.04 & 0.04 & 0.04 & 0.04 & 0.04 \\ \mathrm{MgO} & 0.002 & 0.002 & 0.002 & 0.002 & 0.002 \\ \mathrm{MnO}_{2} & 0.002 & 0.002 & 0.002 & 0.002 & 0.002 \\ & & & & & \\ \mathrm{TOTAL} & 100.004 & 100.004 & 99.998 & 100.008 & 100.004\end{array}$


James C. Marra

WSRC-TR-95-0034, Rev. 0

February 2, 1995

Page 18 of 34

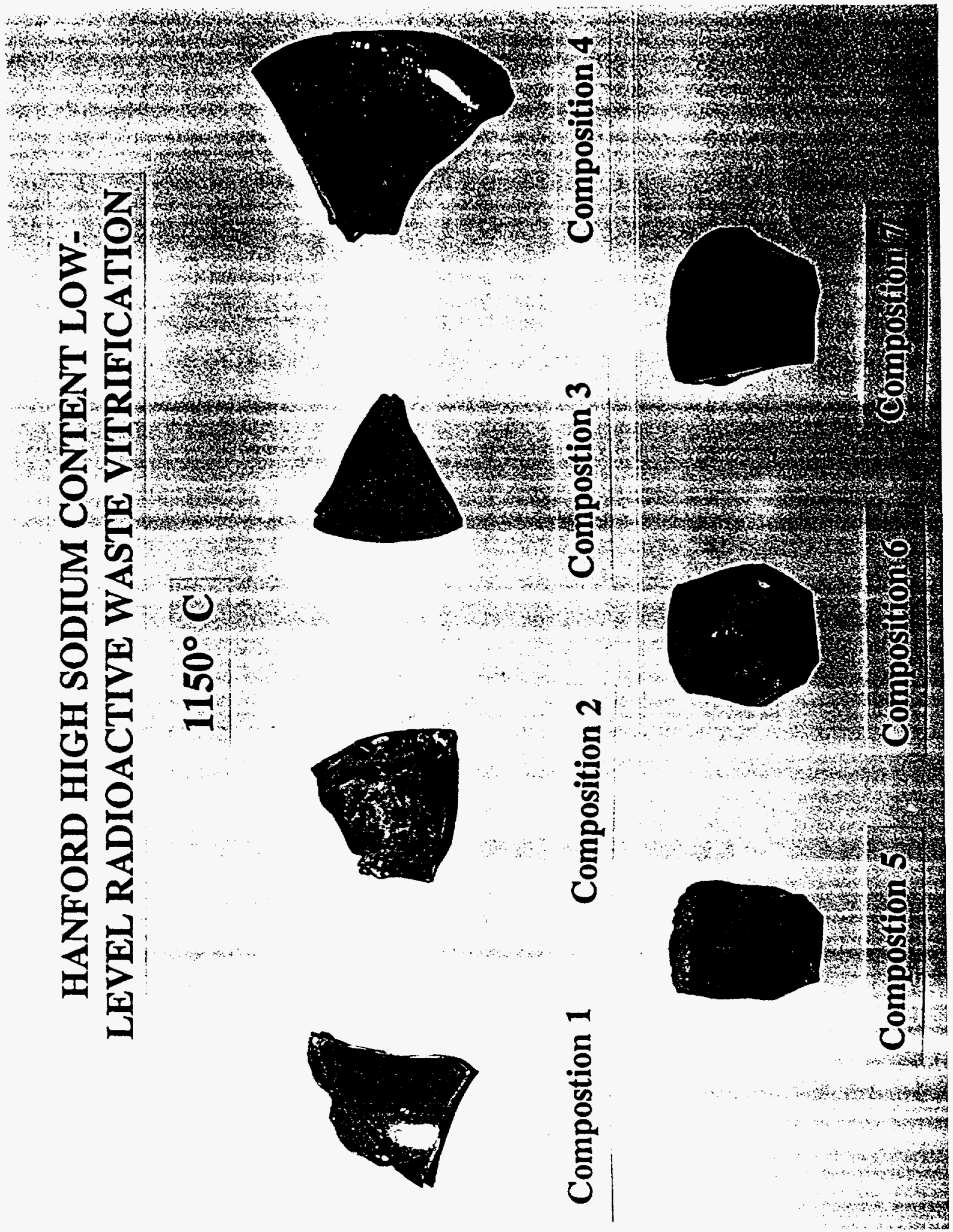

Figure 1. Glass samples from compositions 1-7. 
James C. Marra

WSRC-TR-95-0034, Rev. 0

February 2, 1995

Page 19 of 34

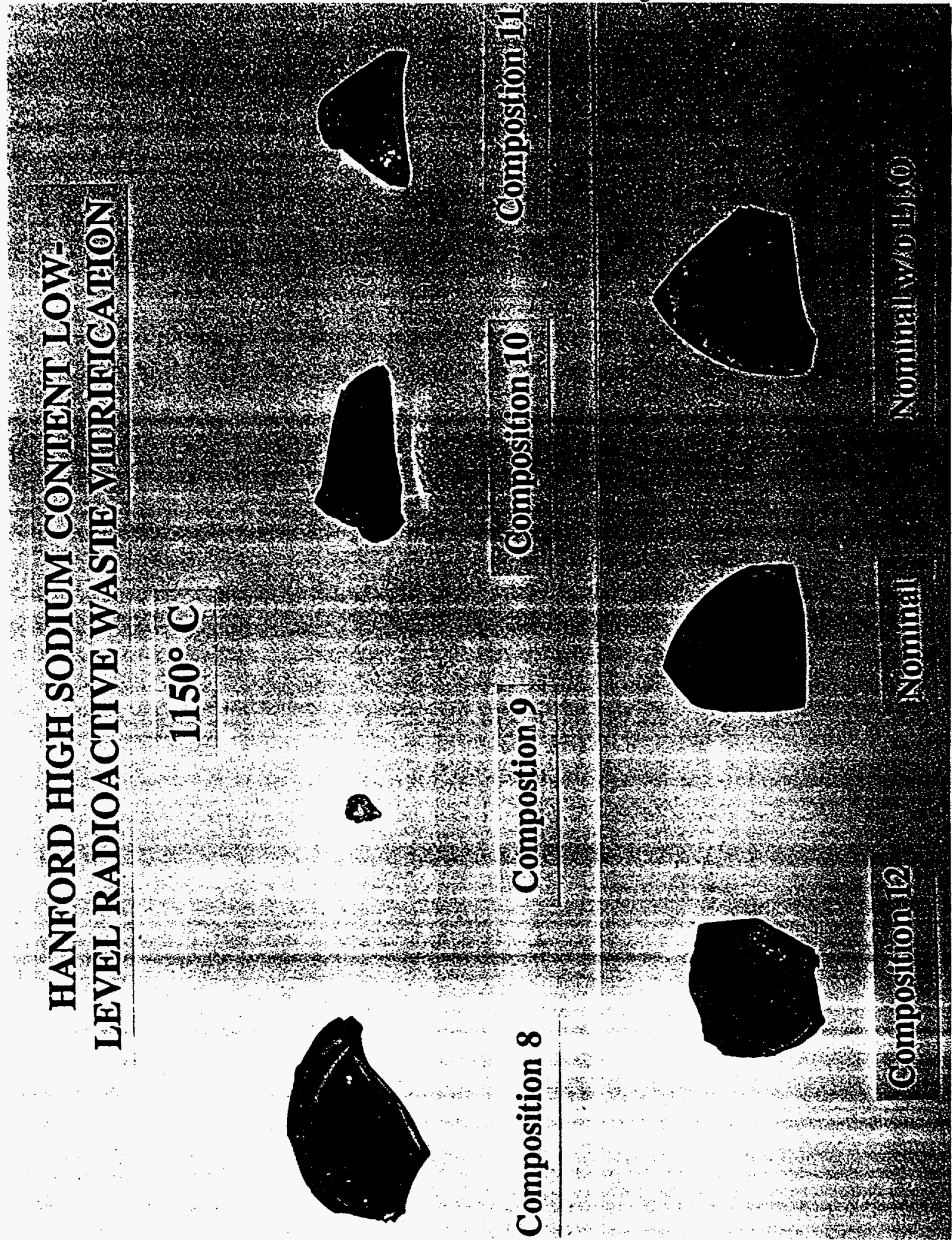

Figure 2. Glass samples from compositions 8-12 and nominal compositions. 
James C. Marra

February 2, 1995
WSRC-TR-95-0034, Rev. 0

Page 20 of 34

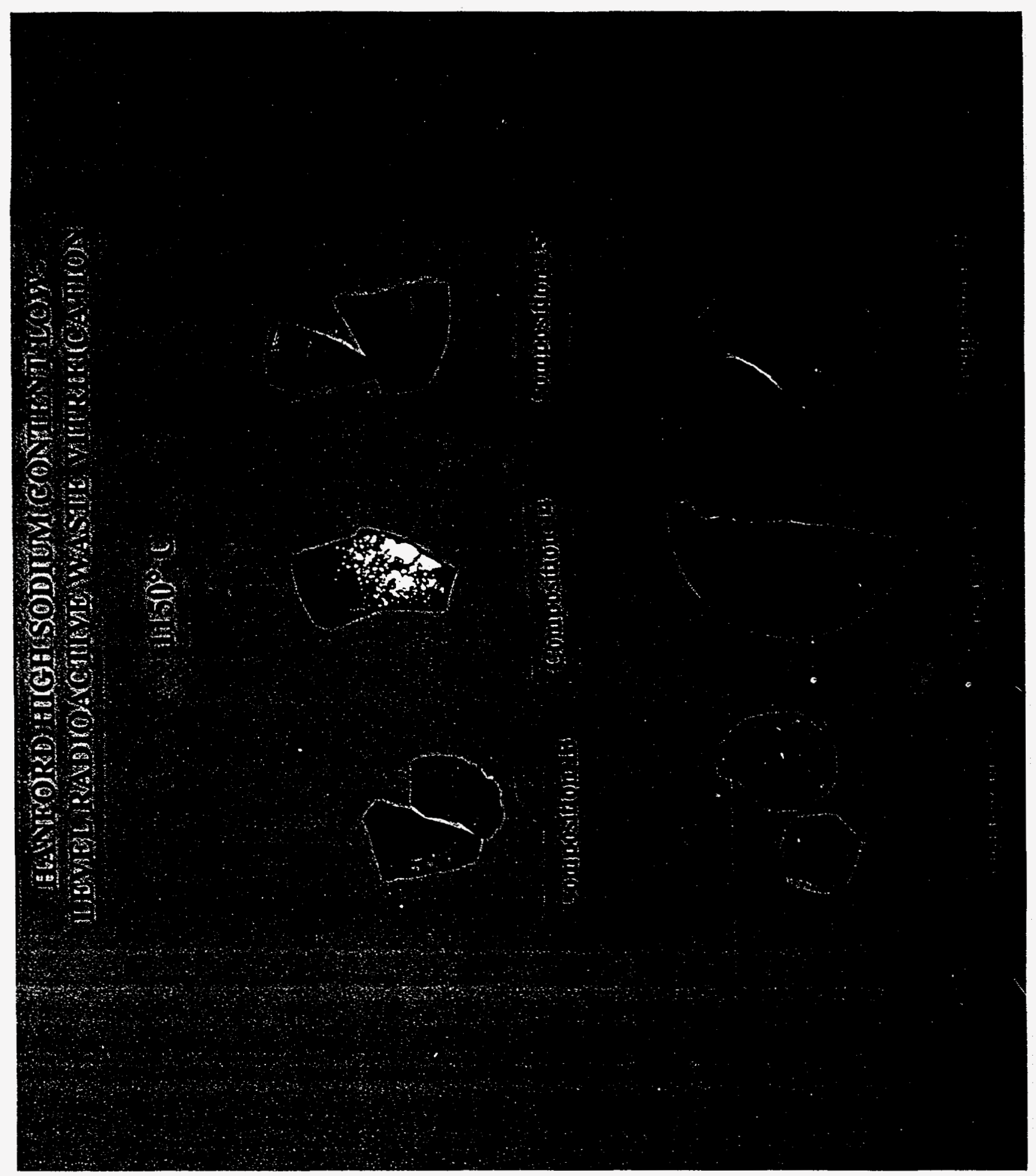

Figure 3. Glass samples from compositions 13-18. 


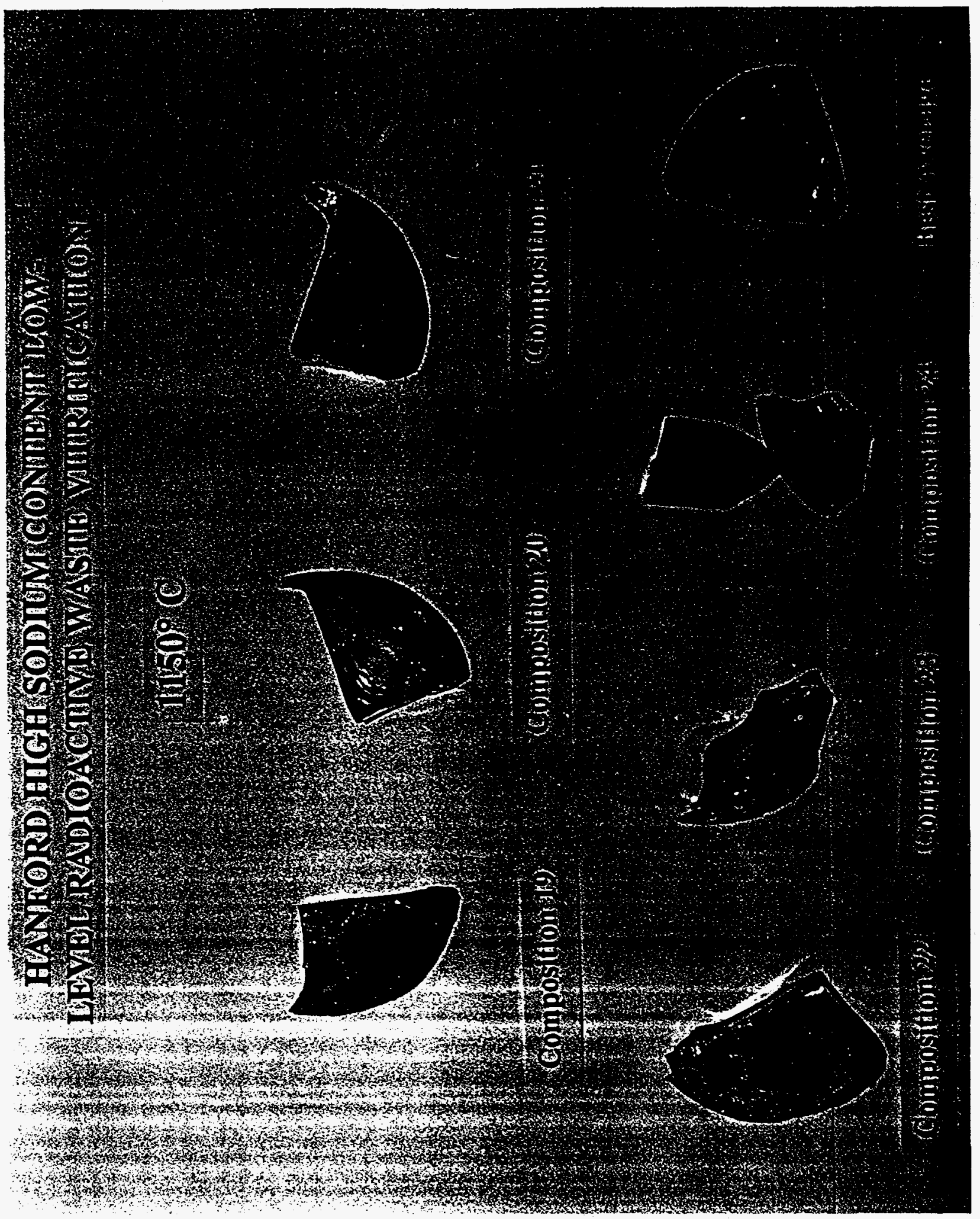

Figure 4. Glass samples from compositions 19-24 and "best average" composition. 
James C. Marra

February 2, 1995
WSRC-TR-95-0034, Rev. 0

Page 22 of 34

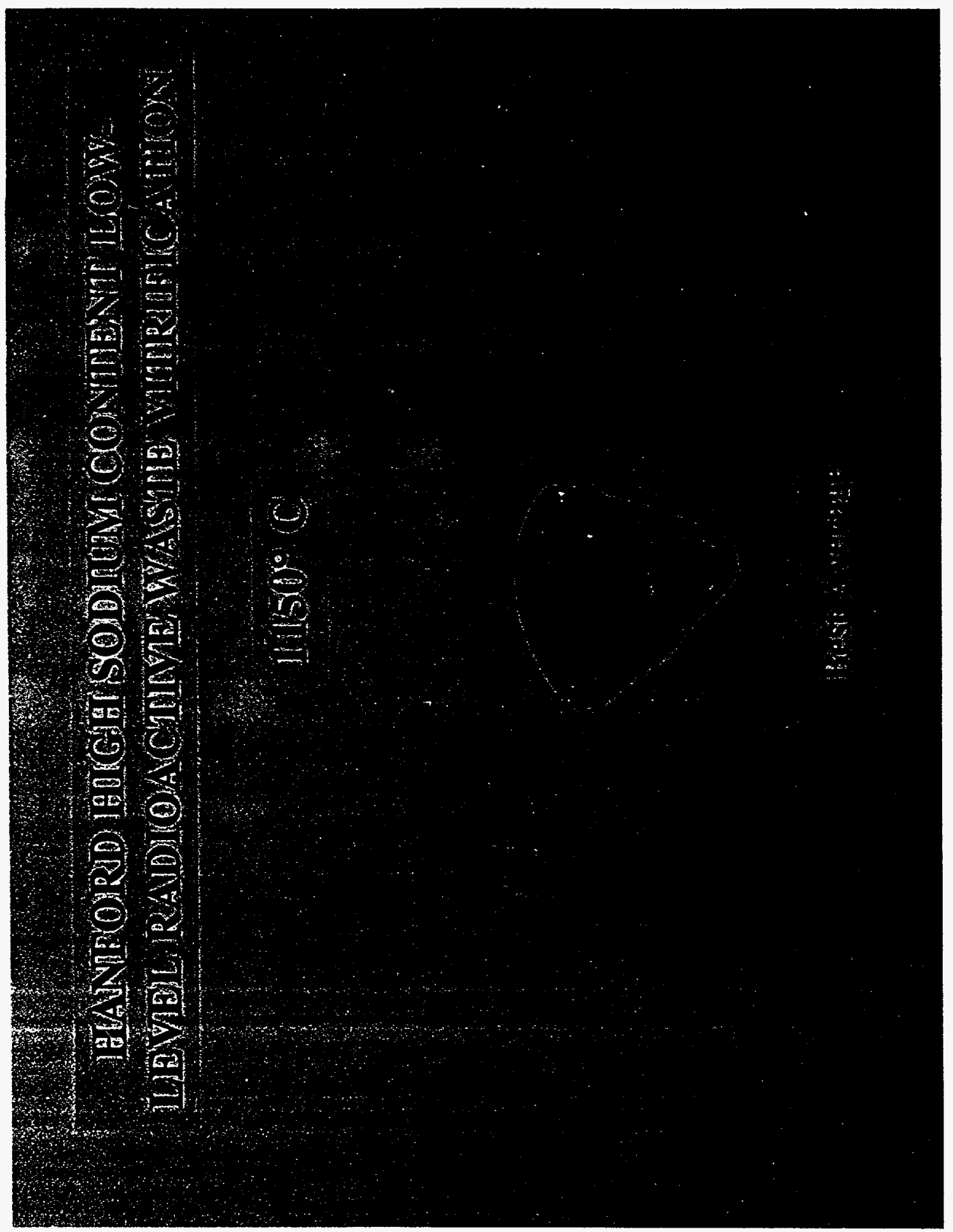

Figure 5. Glass sample from "best average" glass composition. 
James C. Marra

WSRC-TR-95-0034, Rev. 0

February 2, 1995

Page 23 of 34
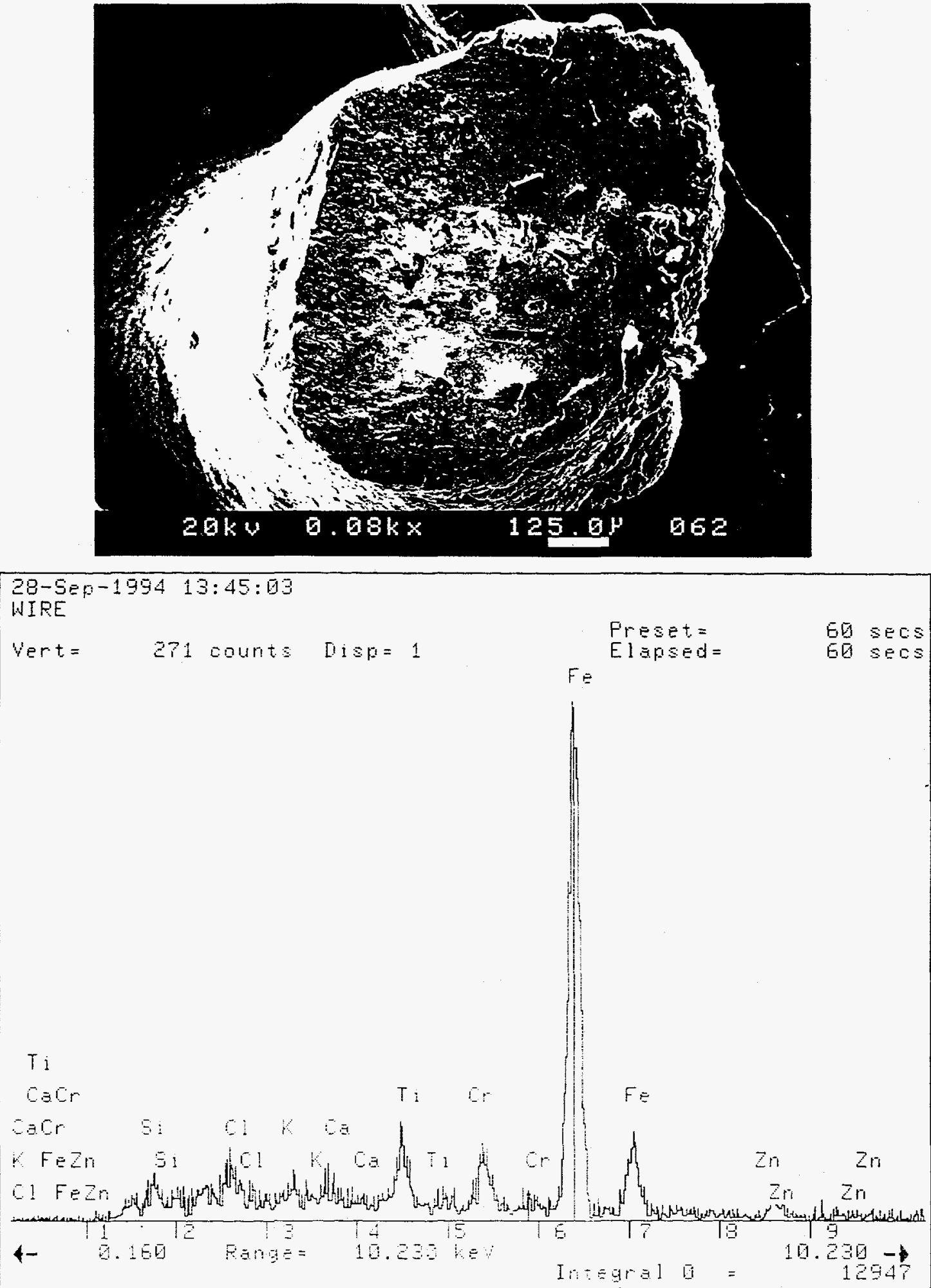

Figure 6. SEM micrograph and EDS spectra of failed pour chamber heater connection wire. 

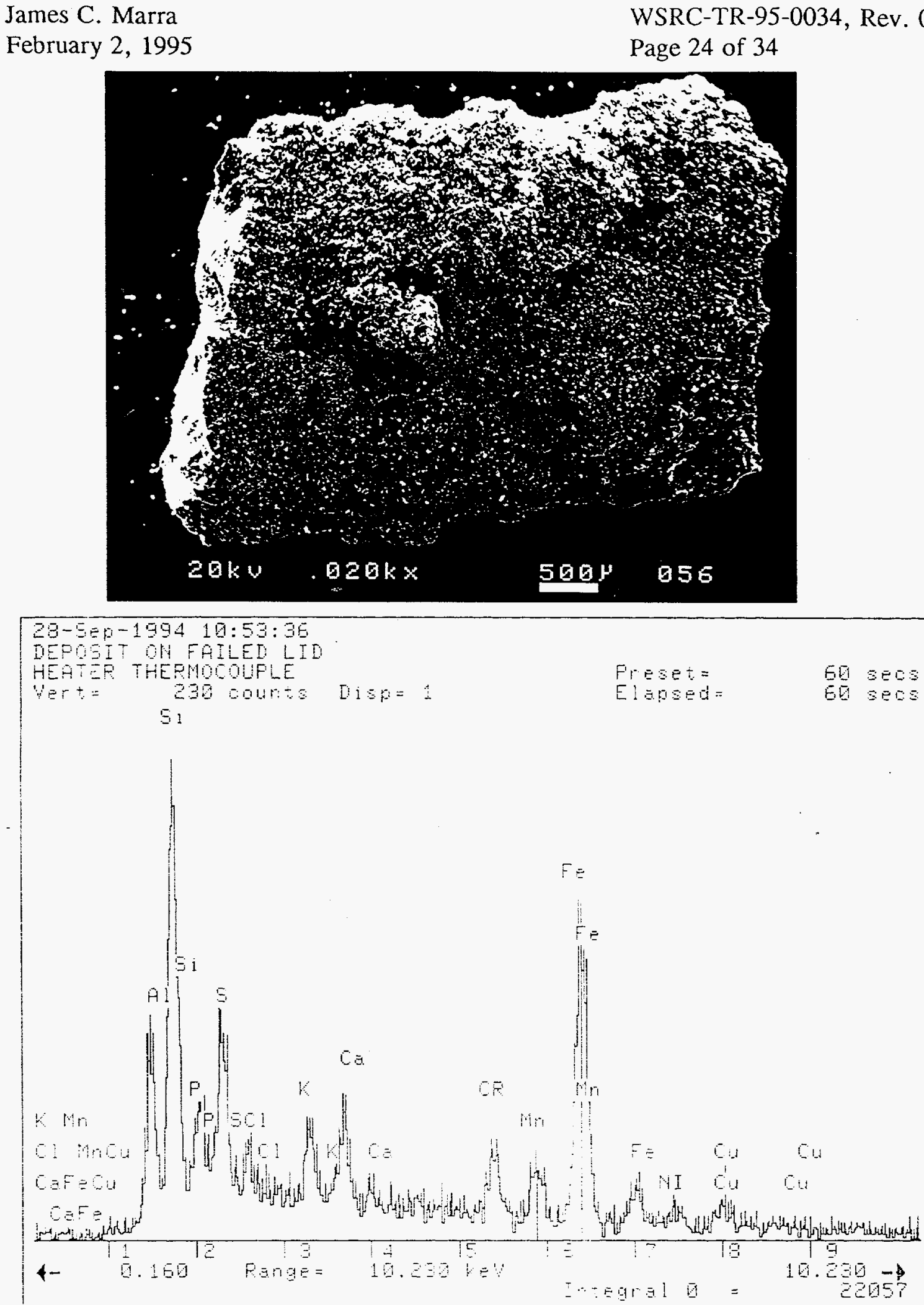

Figure 7. SEM micrograph and EDS spectra of deposits found on a failed lid heater thermocouple. 
James C. Marra

February 2, 1995

WSRC-TR-95-0034, Rev. 0

Page 25 of 34
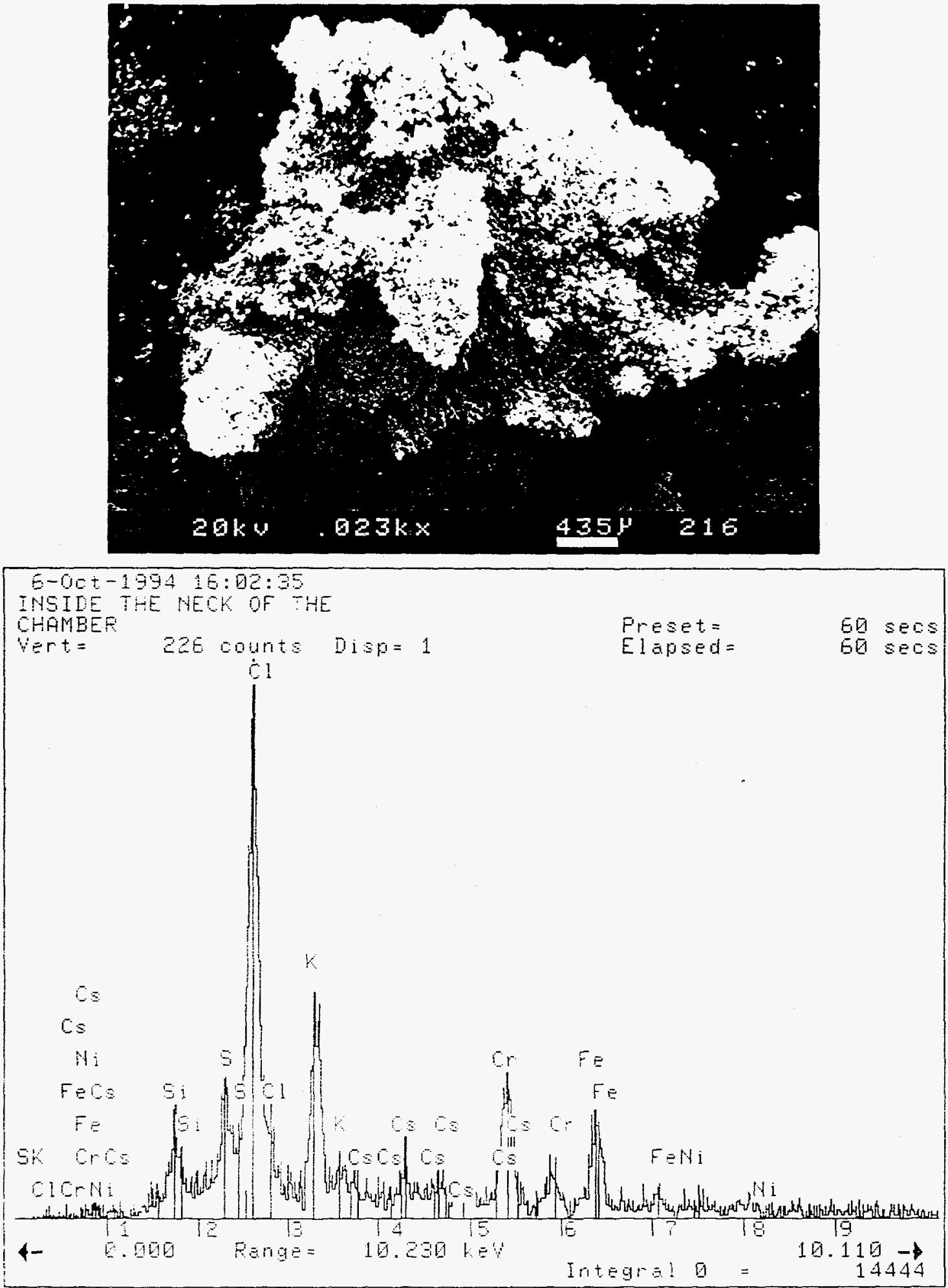

Figure 8. SEM micrograph and EDS spectra of deposits from inside neck of melt chamber. 
James C. Marra

WSRC-TR-95-0034, Rev. 0

February 2, 1995

Page 26 of 34
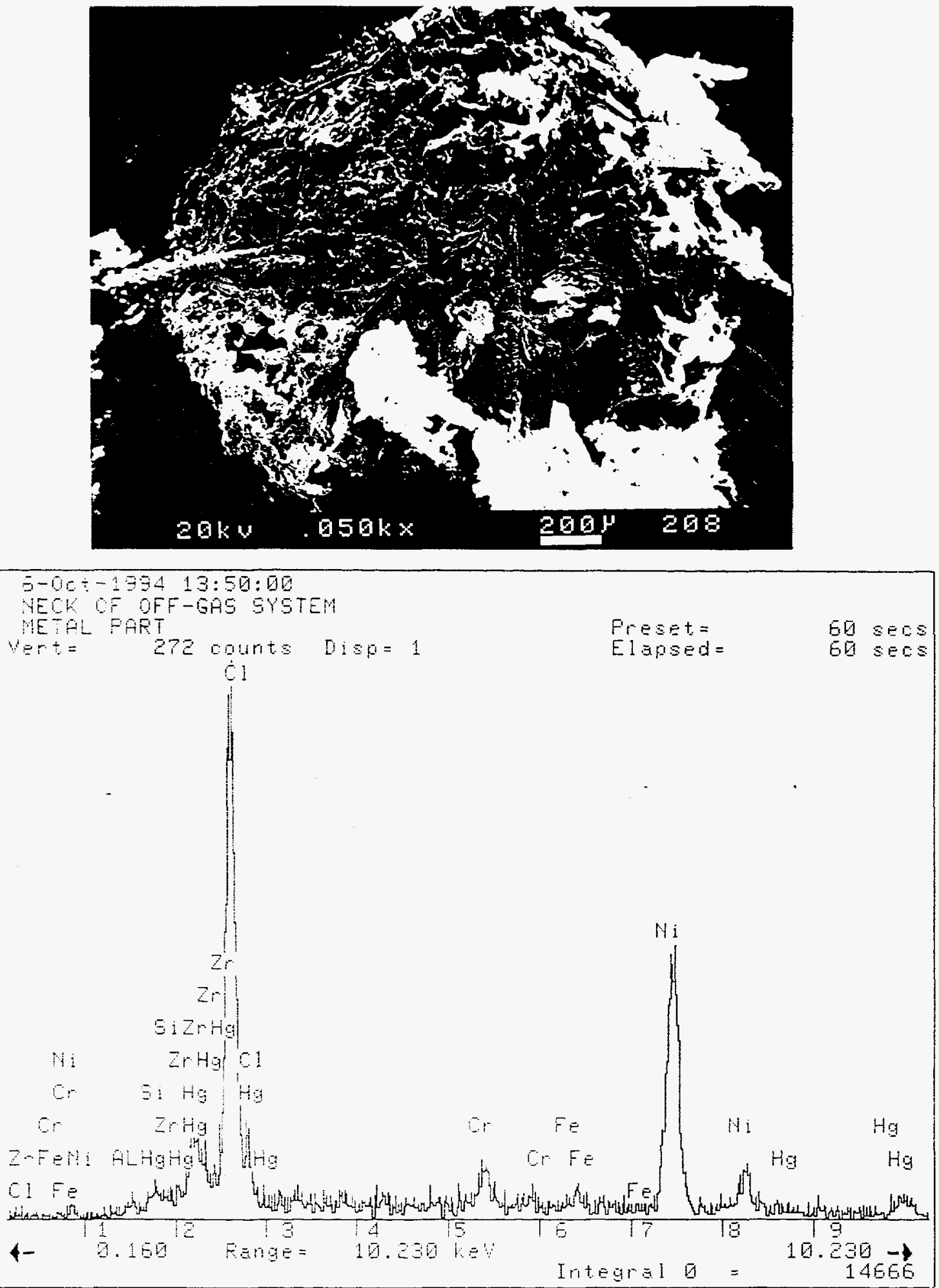

Figure 9. SEM micrograph and EDS spectra of deposits from off-gas connection to the melter. 

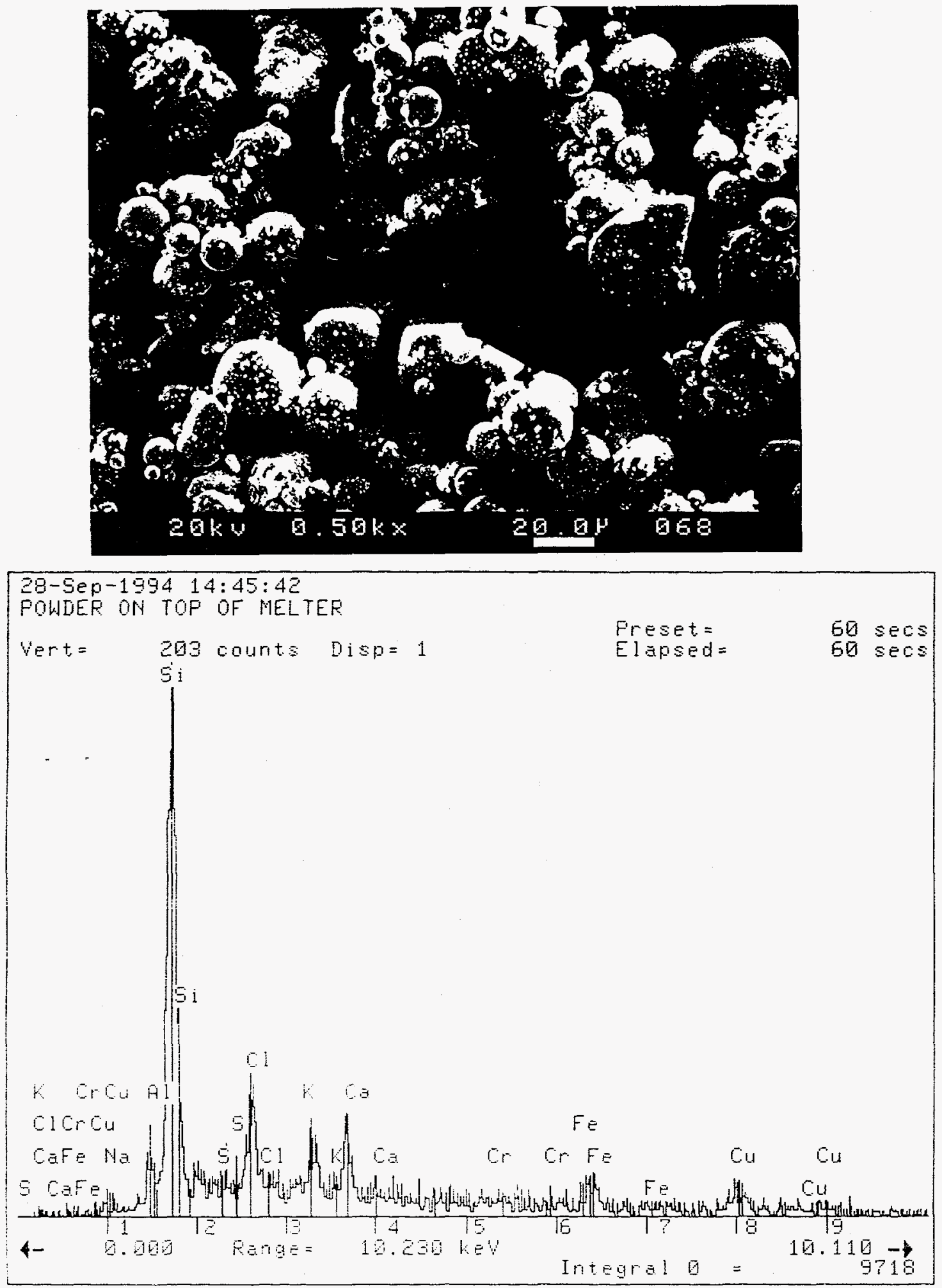

Figure 10. SEM micrograph and EDS spectra of deposits found on top of melter. 
James C. Marra

February 2, 1995

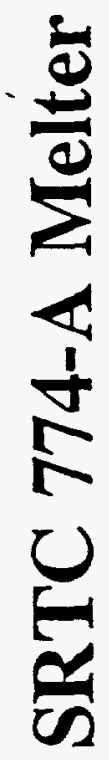

WSRC-TR-95-0034, Rev. 0 Page 28 of 34

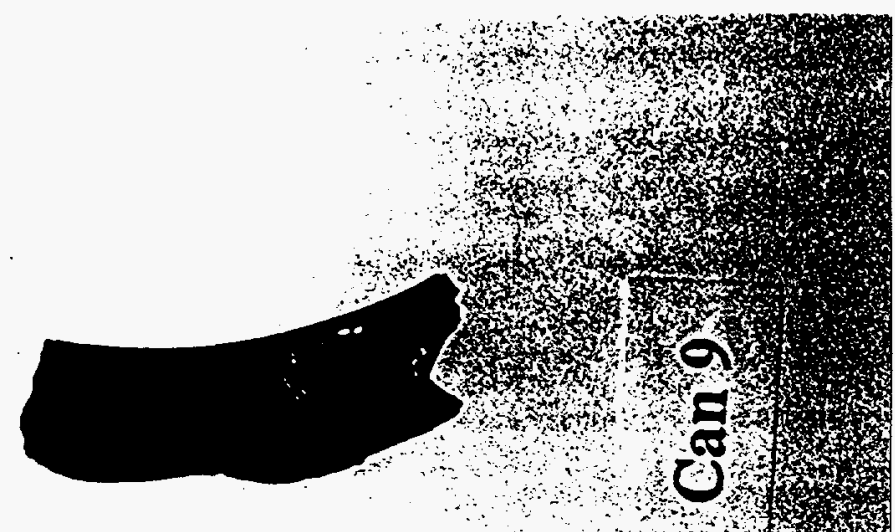

a
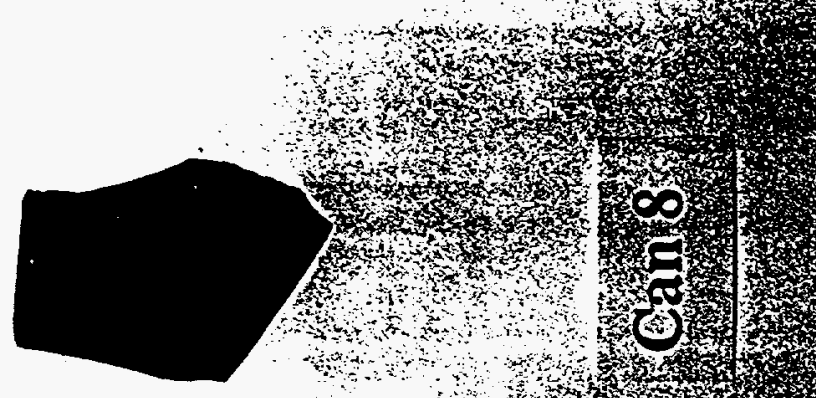

, ot
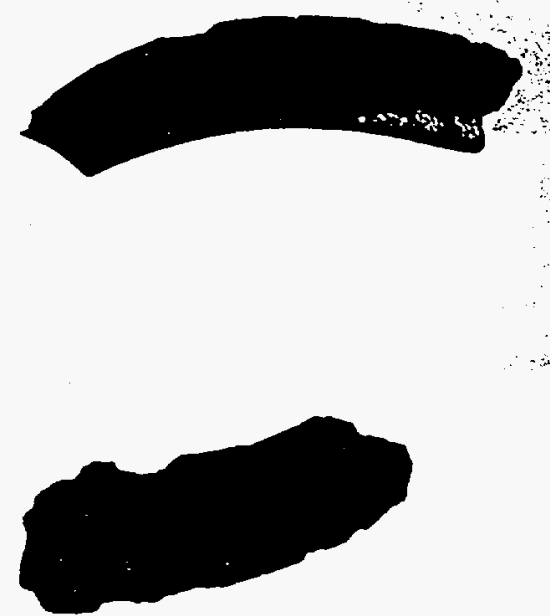

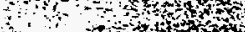

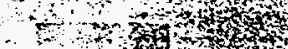
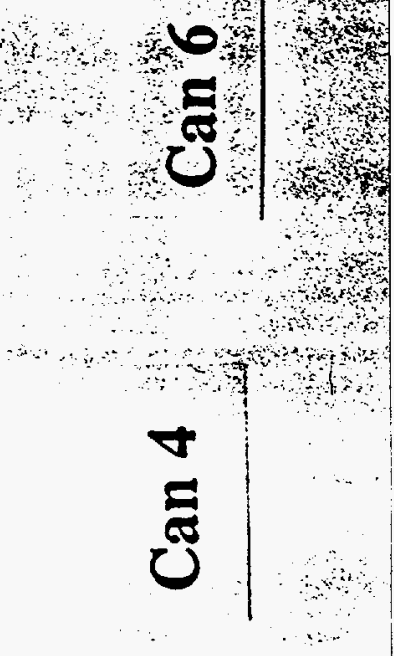

Figure 11. Glass samples from Joule heated melter campaign. 
James C. Marra

February 2, 1995
WSRC-TR-95-0034, Rev. 0

Page 29 of 34

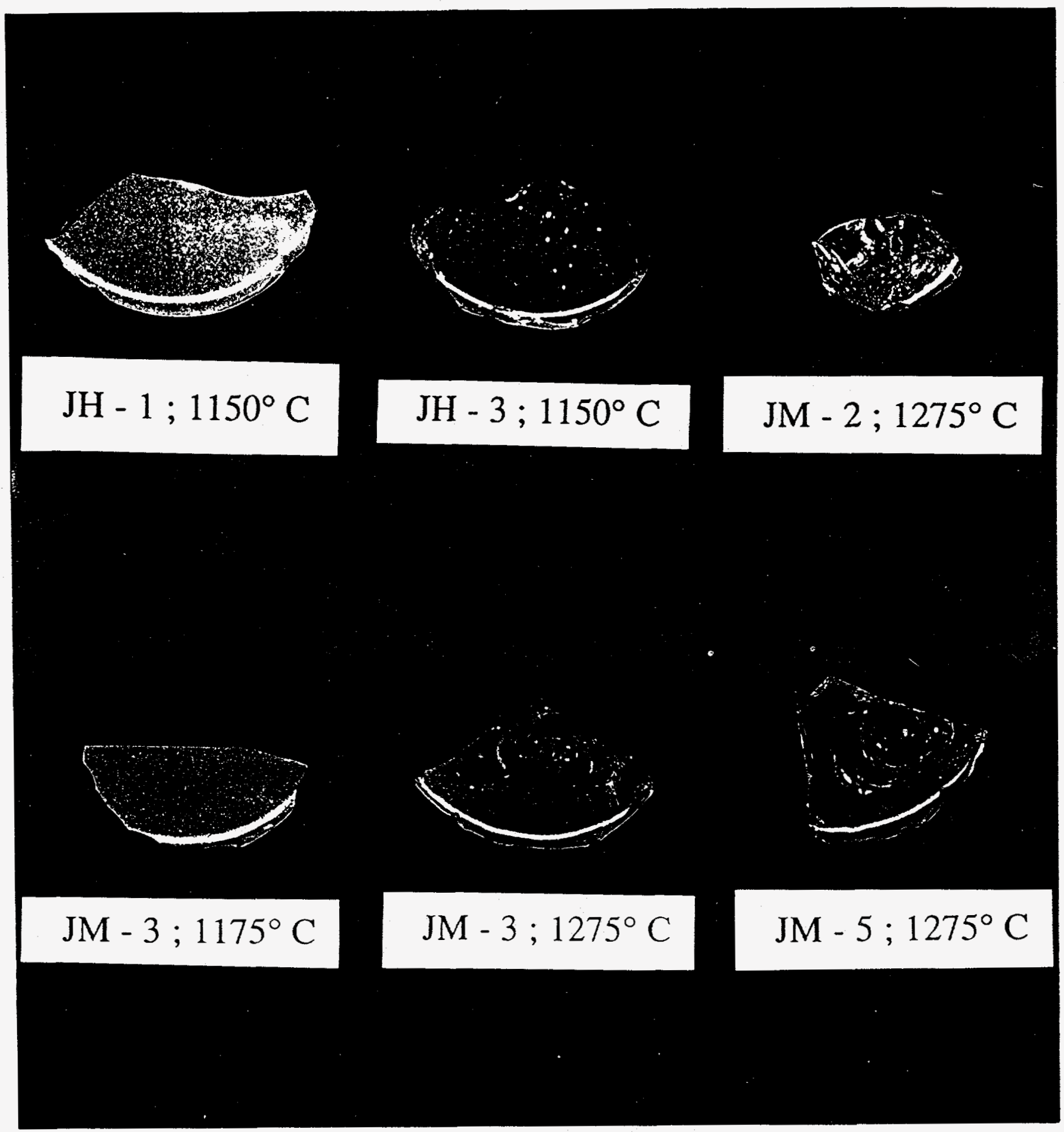

Figure 12. Glasses resulting from low/no boron formulations. 
James C. Marra

February 2, 1995
WSRC-TR-95-0034, Rev. 0

Page 30 of 34

\section{APPENDIX A}

Final Glass Concentrations: Glasses 1 - 5

\section{Glass Composition (wt \%)}

Oxide Comp. $1 \quad$ Comp. $2 \quad$ Comp. $3 \quad$ Comp. $4 \quad$ Comp. 5

$\begin{array}{lccccc}\mathrm{SiO}_{2} & 42.84 & 44.65 & 46.87 & 43.07 & 42.16 \\ \mathrm{Na}_{2} \mathrm{O} & 19.06 & 19.06 & 19.07 & 19.06 & 19.06 \\ \mathrm{Al}_{2} \mathrm{O}_{3} & 13.09 & 13.47 & 14.00 & 18.29 & 17.99 \\ \mathrm{~B}_{2} \mathrm{O}_{3} & 9.43 & 9.80 & 4.23 & 9.50 & 3.77 \\ \mathrm{CaO} & 3.02 & 4.91 & 5.14 & 4.76 & 4.61 \\ \mathrm{ZrO}_{2} & 6.86 & 2.26 & 7.47 & 2.19 & 6.71 \\ \mathrm{Li}_{2} \mathrm{O} & 3.39 & 3.55 & 0.91 & 0.83 & 3.39 \\ \mathrm{~K}_{2} \mathrm{O} & 1.45 & 1.45 & 1.45 & 1.45 & 1.45 \\ \mathrm{SO}_{3} & 0.21 & 0.21 & 0.21 & 0.21 & 0.21 \\ \mathrm{P}_{2} \mathrm{O}_{5} & 0.19 & 0.19 & 0.19 & 0.19 & 0.19 \\ \mathrm{MoO}_{3} & 0.15 & 0.15 & 0.15 & 0.15 & 0.15 \\ \mathrm{Cs}_{2} \mathrm{O} & 0.15 & 0.15 & 0.15 & 0.15 & 0.15 \\ \mathrm{SrO} & 0.11 & 0.11 & 0.11 & 0.11 & 0.11 \\ \mathrm{Cr}_{2} \mathrm{O}_{3} & 0.04 & 0.04 & 0.04 & 0.04 & 0.04 \\ \mathrm{Fe}_{2} \mathrm{O}_{3} & 0.004 & 0.004 & 0.004 & 0.004 & 0.76 \\ \mathrm{MgO}^{\mathrm{MnO}} & 0.002 & 0.002 & 0.002 & 0.002 & 0.002 \\ & 0.002 & 0.002 & 0.002 & 0.002 & 0.002 \\ \mathrm{TOTAL}_{2} & 99.998 & 100.008 & 99.998 & 100.008 & 99.998\end{array}$


James C. Marra

February 2, 1995
WSRC-TR-95-0034, Rev. 0

Page 31 of 34

\section{APPENDIX A (cont.)}

Final Glass Concentrations: Glasses 6 - 10

\section{Glass Composition (wt \%)}

$\begin{array}{lccccc}\text { Oxide } & \text { Comp. 6 } & \text { Comp. 7 } & \text { Comp. 8 } & \text { Comp. 9 } & \text { Comp. 10 } \\ \mathrm{SiO}_{2} & 44.09 & 40.16 & 43.40 & 49.63 & 51.63 \\ \mathrm{Na}_{2} \mathrm{O} & 19.04 & 19.07 & 19.07 & 19.06 & 19.04 \\ \mathrm{Al}_{2} \mathrm{O}_{3} & 18.65 & 17.25 & 13.17 & 14.60 & 15.11 \\ \mathrm{~B}_{2} \mathrm{O}_{3} & 9.72 & 8.83 & 9.51 & 4.45 & 4.67 \\ \mathrm{CaO} & 3.09 & 2.80 & 4.76 & 3.47 & 3.62 \\ \mathrm{ZrO}_{2} & 2.19 & 6.42 & 6.95 & 2.49 & 2.56 \\ \mathrm{Li}_{2} \mathrm{O} & 0.91 & 3.17 & 0.83 & 4.00 & 1.06 \\ \mathrm{~K}_{2} \mathrm{O} & 1.45 & 1.45 & 1.45 & 1.45 & 1.45 \\ \mathrm{SO}_{3} & 0.21 & 0.21 & 0.21 & 0.21 & 0.21 \\ \mathrm{P}_{2} \mathrm{O}_{5} & 0.19 & 0.19 & 0.19 & 0.19 & 0.19 \\ \mathrm{MoO}_{3} & 0.15 & 0.15 & 0.15 & 0.15 & 0.15 \\ \mathrm{Cs}_{2} \mathrm{O} & 0.15 & 0.15 & 0.15 & 0.15 & 0.15 \\ \mathrm{SrO} & 0.11 & 0.11 & 0.11 & 0.11 & 0.11 \\ \mathrm{Cr}_{2} \mathrm{O}_{3} & 0.04 & 0.04 & 0.04 & 0.04 & 0.04 \\ \mathrm{Fe}_{2} \mathrm{O}_{3} & 0.004 & 0.004 & 0.004 & 0.004 & 0.76 \\ \mathrm{MgO} & 0.002 & 0.002 & 0.002 & 0.002 & 0.002 \\ \mathrm{MnO}_{2} & 0.002 & 0.002 & 0.002 & 0.002 & 0.002 \\ \mathrm{TOTAL} & 99.998 & 100.008 & 99.998 & 100.008 & 99.998\end{array}$


James C. Marra

February 2, 1995
WSRC-TR-95-0034, Rev. 0

Page 32 of 34

\section{APPENDIX A (cont.)}

Final Glass Concentrations: Glasses 11 - 15

Glass Composition (wt \%)

Oxide Comp. 11 Comp. 12 Comp. 13 Comp. $14 \quad$ Comp. 15

$\begin{array}{lccccc}\mathrm{SiO}_{2} & 44.65 & 44.88 & 52.87 & 46.61 & 49.70 \\ \mathrm{Na}_{2} \mathrm{O} & 19.06 & 19.06 & 19.06 & 19.06 & 19.06 \\ \mathrm{Al}_{2} \mathrm{O}_{3} & 18.82 & 18.90 & 13.77 & 18.14 & 13.16 \\ \mathrm{~B}_{2} \mathrm{O}_{3} & 4.00 & 4.07 & 4.75 & 4.22 & 10.94 \\ \mathrm{CaO} & 3.10 & 4.91 & 5.81 & 3.25 & 3.47 \\ \mathrm{ZrO}_{2} & 7.16 & 2.26 & 1.21 & 6.18 & 1.13 \\ \mathrm{Li}_{2} \mathrm{O} & 0.91 & 3.62 & 0.23 & 0.23 & 0.23 \\ \mathrm{~K}_{2} \mathrm{O} & 1.45 & 1.45 & 1.45 & 1.45 & 1.45 \\ \mathrm{SO}_{3} & 0.21 & 0.21 & 0.21 & 0.21 & 0.21 \\ \mathrm{P}_{2} \mathrm{O}_{5} & 0.19 & 0.19 & 0.19 & 0.19 & 0.19 \\ \mathrm{MoO}_{3} & 0.15 & 0.15 & 0.15 & 0.15 & 0.15 \\ \mathrm{Cs}_{2} \mathrm{O} & 0.15 & 0.15 & 0.15 & 0.15 & 0.15 \\ \mathrm{SrO} & 0.11 & 0.11 & 0.11 & 0.11 & 0.11 \\ \mathrm{Cr}_{2} \mathrm{O}_{3} & 0.04 & 0.04 & 0.04 & 0.04 & 0.04 \\ \mathrm{Fe}_{2} \mathrm{O}_{3} & 0.004 & 0.004 & 0.004 & 0.004 & 0.76 \\ \mathrm{MgO} & 0.002 & 0.002 & 0.002 & 0.002 & 0.002 \\ \mathrm{MnO}_{2} & 0.002 & 0.002 & 0.002 & 0.002 & 0.002 \\ & & & & & \\ \mathrm{TOTAL} & 100.008 & 100.008 & 100.008 & 99.998 & 99.998\end{array}$


James C. Marra

February 2, 1995
WSRC-TR-95-0034, Rev. 0

Page 33 of 34

\section{APPENDIX A (cont.)}

Final Glass Concentrations: Glasses 16 - 20

Glass Composition (wt \%)

Oxide Comp. 16 Comp. 17 Comp. 18 Comp. $19 \quad$ Comp. 20

$\begin{array}{lccccc}\mathrm{SiO}_{2} & 47.82 & 48.65 & 43.07 & 50.31 & 47.14 \\ \mathrm{Na}_{2} \mathrm{O} & 19.06 & 19.06 & 19.06 & 19.06 & 19.06 \\ \mathrm{Al}_{2} \mathrm{O}_{3} & 12.78 & 10.52 & 14.82 & 16.78 & 11.65 \\ \mathrm{~B}_{2} \mathrm{O}_{3} & 10.56 & 12.14 & 10.79 & 6.03 & 11.77 \\ \mathrm{CaO} & 3.32 & 3.40 & 4.76 & 5.51 & 5.21 \\ \mathrm{ZrO}_{2} & 1.06 & 3.92 & 3.47 & 0 & 0 \\ \mathrm{Li}_{2} \mathrm{O} & 3.09 & 0 & 1.73 & 0 & 2.87 \\ \mathrm{~K}_{2} \mathrm{O} & 1.45 & 1.45 & 1.45 & 1.45 & 1.45 \\ \mathrm{SO}_{3} & 0.21 & 0.21 & 0.21 & 0.21 & 0.21 \\ \mathrm{P}_{2} \mathrm{O}_{5} & 0.19 & 0.19 & 0.19 & 0.19 & 0.19 \\ \mathrm{MoO}_{3} & 0.15 & 0.15 & 0.15 & 0.15 & 0.15 \\ \mathrm{Cs}_{2} \mathrm{O} & 0.15 & 0.15 & 0.15 & 0.15 & 0.15 \\ \mathrm{SrO} & 0.11 & 0.11 & 0.11 & 0.11 & 0.11 \\ \mathrm{Cr}_{2} \mathrm{O}_{3} & 0.04 & 0.04 & 0.04 & 0.04 & 0.04 \\ \mathrm{Fe}_{2} \mathrm{O}_{3} & 0.004 & 0.004 & 0.004 & 0.004 & 0.76 \\ \mathrm{MgO}^{\mathrm{MnO} O} & 0.002 & 0.002 & 0.002 & 0.002 & 0.002 \\ \mathrm{MnO}_{2} & 0.002 & 0.002 & 0.002 & 0.002 & 0.002 \\ \mathrm{TOTAL} & 99.998 & 99.998 & 100.008 & 99.998 & 100.008\end{array}$


James C. Marra

February 2, 1995
WSRC-TR-95-0034, Rev. 0

Page 34 of 34

\title{
APPENDIX A (cont.)
}

Final Glass Concentrations: Glasses 21 - 24, Best Average

\author{
Glass Composition (wt \%)
}

Oxide Comp. $21 \quad$ Comp. 22 Comp. 23 Comp. $24 \quad$ Best Avg.

$\begin{array}{lccccc}\mathrm{SiO}_{2} & 45.10 & 44.65 & 43.07 & 45.48 & 46.08 \\ \mathrm{Na}_{2} \mathrm{O} & 19.06 & 19.06 & 19.06 & 19.06 & 19.06 \\ \mathrm{Al}_{2} \mathrm{O}_{3} & 15.42 & 16.63 & 13.16 & 17.76 & 15.35 \\ \mathrm{~B}_{2} \mathrm{O}_{3} & 13.58 & 7.54 & 11.62 & 6.34 & 9.28 \\ \mathrm{CaO} & 3.17 & 4.91 & 3.02 & 3.17 & 4.15 \\ \mathrm{ZrO}_{2} & 0 & 4.90 & 5.58 & 5.88 & 2.49 \\ \mathrm{Li}_{2} \mathrm{O} & 1.36 & 0 & 2.19 & 0 & 1.28 \\ \mathrm{~K}_{2} \mathrm{O} & 1.45 & 1.45 & 1.45 & 1.45 & 1.45 \\ \mathrm{SO}_{3} & 0.21 & 0.21 & 0.21 & 0.21 & 0.21 \\ \mathrm{P}_{2} \mathrm{O}_{5} & 0.19 & 0.19 & 0.19 & 0.19 & 0.19 \\ \mathrm{MoO}_{3} & 0.15 & 0.15 & 0.15 & 0.15 & 0.15 \\ \mathrm{C}_{2} \mathrm{O} & 0.15 & 0.15 & 0.15 & 0.15 & 0.15 \\ \mathrm{SrO} & 0.11 & 0.11 & 0.11 & 0.11 & 0.11 \\ \mathrm{Cr}_{2} \mathrm{O}_{3} & 0.04 & 0.04 & 0.04 & 0.04 & 0.04 \\ \mathrm{Fe}_{2} \mathrm{O}_{3} & 0.004 & 0.004 & 0.004 & 0.004 & 0.76 \\ \mathrm{MgO}^{\mathrm{MnO}} & 0.002 & 0.002 & 0.002 & 0.002 & 0.002 \\ & 0.002 & 0.002 & 0.002 & 0.002 & 0.002 \\ \mathrm{TOTAL}_{2} & 99.998 & 99.998 & 100.008 & 99.998 & 99.998\end{array}$

